\title{
THE ROLE OF ENGLISH COMMUNICATION COMPETENCE TOWARD STAR HOTEL STAFFS' WORKING ACHIEVEMENT IN PALEMBANG
}

\author{
Ega Leovani \\ Faculty of Business and Accounting, Universitas Katolik Musi Charitas Palembang \\ egaleovani@yahoo.com \\ Anastasia Ronauli Hasibuan \\ Faculty of Business and Accounting, Universitas Katolik Musi Charitas Palembang \\ anastasiaronauli@gmail.com
}

\begin{abstract}
Considering the implementation of ASEAN Economic Community and Asian Games 2018, potential hotels are urged to prepare qualified and competitive human resource. Language is believed as a means of communication among people involved in these international events. People around the world would stay at certain hotel, and English communication competence might relate the hotel guests and the employees as service provider agent. This study aims to excavate the role of English communication competence toward employees' working achievement. About three hundred and fifty-three employes from forty-four different star hotels in Palembang were involved as the sample. The data was collected by administering two kinds of instruments, namely speaking test (to obtain the condition of their communication competence) and questionnaires concerning superior's judgement on employees' working achievement. The results were obtained through the descriptive, percentage, and statistical analysis which was aimed to find out the significant influence of English communication competence toward employee achievement. The findings showed that there was positive influence of English communication competence toward employees' achievement.
\end{abstract}

Keywords: communication competence, language, employees's achievement .

\begin{abstract}
Abstak
Mengingat pentingnya mempersiapkan sumber daya manusia menuju isu Masyarakat Ekonomi ASEAN dan Asian Games 2018, maka dirasa perlu untuk setiap hotel potensial menghasilkan sumber daya manusia yang berkualitas dan memiliki daya saing. Bahasa diyakini menjadi alat komunikasi di antara sistem perdagangan internasional yang akan diterapkan pada masa yang akan datang ini. Masyarakat dari seluruh dunia akan tinggal di hotel-hotel tertentu dan kompetensi berkomunikasi dalam Bahasa Inggris dapat menghubungkan pembicaraan antara tamu hotel dan karyawan hotel sebagai agen penyedia layanan. Penelitian ini bertujuan untuk menggali peran kompetensi berkomunikasi Bahasa Inggris terhadap kinerja karyawan. Sekitar tiga ratus lima puluh tiga karyawan dari 44 hotel berbintang di Palembang dilibatkan menjadi sampel penelitian ini. Teknik pengumpulan data menggunakan dua jenis instrumen yaitu tes berbicara (untuk memperoleh kondisi kompetensi berkomunikasi karyawan) dan kuesioner mengenai penilaian atasan terhadap kinerja karyawannya. Data yang diperoleh diolah dengan menggunakan teknik analisis deksriptif, persentase, dan statistik yang bertujuan untuk menemukan pengaruh signifikan dari kompetensi berkomunikasi Bahasa Inggris terhadap kinerja karyawan. Hasil dari penelitian ini menunjukkan bahwa kompetensi berkomunikasi Bahasa Inggris berpengaruh positif terhadap kinerja karyawan.
\end{abstract}


Kata Kunci: kemampuan berkomunikasi, bahasa, kinerja karyawan JEL: J81

\section{Research Background}

Business organizations must implement adaptation and reinforcement in order to accomplish future challenges in this globalization era. Thus, companies require competent and qualified human resources. Employees as the real representation of human resources play the role as designer, performer as well as determiner of organization goal attainment. This concept is discussed briefly in the field of human resources management which covers: planning, organizing, actuating and controlling as well as staffing. Since this field is also considered very important in achieving the organization goal, results of experience and sistematic research are published to develop references in practical human resource. As stated by Rivai (2005), management is a set of knowledge on how to manage the human resources.

In the field of hotel marketing, employees often experience difficulties in communicating available services. The use of English terms is one of the practical obstacles which provoke ineffective communication between hotel staffs and customer and ultimately generate incorrect meaning perception. This situation indicates the need of English language mastery and communication improvement.

Language is an important aspect in human interaction and social contact. It is also viewed as someone's personal reflection which is interpreted into sense, thought and attitude. Ocassionally, someone might be very intelligent with brilliant ideas, but they cannot deliver the ideas due to communication problems. Developing language communication competence is the answer to this situation. The presence of language attitude (the awareness of language norms) and thinking is the hub of consideration why people speak the language, in addition, knowledge is the objective of all. Furthermore, English language mastery is not always priorly possessed by employees in starting their career in a new working place. The demand of language mastery would be intensively requested by the time someone is promoted to a better position and a more challenging working performance. Regina dan Chinwe (2014) stated that in developing English communication competence, language users should have not only the ability to understand the language use, but also the ability to understand linguistic variances in context. Therefore, there are various things should be known before using the language to communicate such as linguistic competence, social-culture competence, time and place of the language use, and utilization strategy.

The term communication is announced into two original words which unitely mean competence to communicate (Bagaric 2007). Competence is one of the controversial terms in applied linguistics. In addition, Chomsky (1965) outlined the difference between competence and performance. Competence is defined as speaker's intuitive knowledge toward grammatical rules of mother language. Meanwhile, performance is production practice by implementing previously known grammatical rules. Other language experts offer different view on defining the competence. Hymes (1972) stated that children learn the knowledge of sentence use not only grammatically but also contextually. Hymes believes that the children know when they can exactly speak, what to say, with whom, and how. In line with Hymes' idea, Radford (1988) asserted that grammatical competence is not the only element to reflect someone's language competence, pragmatic competence is also required in recogizing the oral and written form.

Since communication competence also involves the social and interactional context, Spitzberg (2003) emphasized the importance of communication skill evaluation where someone might demonstrate their skills toward wider situation.

In this globalization era, English is used around the world. It is considered as a means of communication to relate people among nations, and it covers many sectors including business, education, engineering, technology, banking, tourism, etc. Moreover, the communication tools 
available around us are supported by the use of this language. Amongst various potential benefits of English language use, EF EPI (2015) claimed that the most essential concern is the communication teaching practices. Based on the survey which was analyzed from more than 910.000 adults who took online English test in 2014, the average level of adult English proficiency in the world has risen slightly since 2014. Thereupon, it is also reported that the gap between the highest and lowest proficiency countries has widened. European countries are identified as they dominate the index which means that they fill the highest proficiency bands. Meanwhile, Asia has a high level of English skill diversity, with three countries in the High Proficiency bands as well as several in the lowest proficiency band. Sixteen Asian countries were analyzed out of seventy subjects by the EF EPI, and only six countries had higher English proficiency score than the average point (53.21). Indonesia was in the 32nd place with EF EPI score of 52.91 and categorized in moderate proficiency. With the increasingly international economies, Asian countries invest in English training as a tool for accelerating globalization. Some of the effective strategies to obtain higher English proficiency level are focusing on practical communication skills, training English for communication, developing effective English assessment tools, and investing in technology and online learning tools.

Managers as a part of the organization structure would take responsible of this communication problem by having sufficient competence to proceed the effective working environment. This demand is in line with Davis et al. (1996) about several communication competencies should be possessed by a manager, namely speaking effectively, developing open communication, listening others, presenting paper, and preparing written communication. These language competencies would also be useful in socialization context of company's new policy toward employees. Changing resistance as the reaction toward new policy would enable manager to activate their language competence to build employees' conviction and comprehension. Managers are also required to develop their language competence in building good interaction for cooperation need with other companies. It is clearly seen that a communicative manager with good language communication competence might ensure a successful business.

Working achievement is designed as the result of efforts determined by personal characteristic competence as well as the perception toward the role of the work itself (Sutrisno 2011). Then, according to Mangkunegara (2009), working achievement is the result of work achieved qualitatively and quantitatively by an employee in conducting their function respoinsibly. Working achievement could also mean the result of work which is assigned considering their proficiency, experience, sincerity, and time (Hasibuan 2008).

It can be concluded that working achievement is the result of employee's effort and sincerity in responsibly conducting the assigned function considering their proficiency, experience, sincerity, and time.

Indonesia as a part of the Association of South East Asian nations (ASEAN) was about welcome the new integration program of ASEAN namely ASEAN Economic Community (AEC) 2015. Members of ASEAN agreed to implement AEC 2015 as the creation of single market and production which enables free flows of goods, services, investment, capital and people to increase the stability of political and economic systems as well as the social cultural exchange. According to Choomthong (2013), the fields that would be firstly affected were construction, business, and medical services. Human resource capacity might be the main concern of taking on this event since the ASEAN members had different language use and social culture condition. Therefore, in the ASEAN Secretariat (2008b) English was chosen as the language of administration for ASEAN and is often the language that users across ASEAN have in common. Dulyadaweesid (2003) stated that education is seen as a key factor in preparing the citizens of the Member States for the increased integration and resulting competitiveness. English language education is seen as a necessity to prepare human resources to compete effectively and make use of technical, business, and negotiation skills areas. 
Specifically for business area, Didiot-Cook at al. (2000) conducted a survey on language needs in business for European multinational companies. It was found that companies expect to recruit employees with at least an advanced level of English competence. Viewed from the four English language skills, oral skills which involve listening and speaking are considered far more important than written ones. It is regarded so since business communication mostly covers the setting of meetings, negotiations, and problem solving context. Thus, the demanded English competency of AEC context is in accordance with the needs of business setting.

An international event of Asian Games 2018 would be upcomingly held in Jakarta and Palembang. Afterward, it was believed that this opportunity grabbed the attention of hotel employers. About 9.704 athletes from 45 countries in Asia continent would come over and the star hotels might be in their list to stay. Hence, it was important for the hotel employers to set up a good preparation in terms of public service and human resources readiness. Hotel staffs should have good communication skill to interact with the foreign visitors by using English as the international language. Thereof, considering the requirement of setting up good preparation toward the need of having good communication skills, this study focused on digging up the role of English communication competence toward star hotel staffs' working achievement by formulating two research problems namely finding out the English communication competence level of the star hotel staffs and significant influence of English communication competence toward star hotel staffs' working achievement. It was expected that this study would be useful for the writers, hotel staffs and employers, and future researchers.

Previous study was investigated by Nurlaila (2003) entitled "The Correlation between English Language Competence and Employees Performance in PT. Elang Express Surabaya”. This cross sectional analysis research aimed to examine the correlation between English language competence and working performance. By implementing total population method, forty-seven employees were involved as the sample from a shipping and forwarding company of PT. Elang Express. In addition, this study used several instruments such as English written test, attitude, behavior and performance scale questionnaire, as well as interview to obtain the data. It was found out that language knowledge is not the only factor of attitude former and attitude des not directly expres attitude. Better attitude of speaking English is caused by working demand and better performance is mostly influenced by good compensation system. This study proposed the issue of English language training effectiveness and efficiency in working environment since company spend higher cost for executing this program.

\section{Research Method}

This study involved two variables namely independent and dependent variables. The independent variable explained and influenced other variable (Supomo dan Indriantoro 2002), which was the English Communication Competence. Meanwhile, the dependent variable was influenced by independent variable, namely working achievement.

The population of this study was the employees of star hotels in Palembang. Meanwhile, the sample was population element as measurement subject of research unit which represented the information of the population itself (Cooper dan Schindler 2001). The sample of this study were selected by implementing proportional cluster random sampling method, where the population was grouped based on working place. Then simple random sampling method (Sekaran 2000) was executed to select the $30 \%$ of the total employess from particular hotel. The proportion of the sample is illustrated as follows: 
Tabel 1. Sample

\begin{tabular}{|c|c|c|c|}
\hline No & Hotel & Employees & Sample \\
\hline 1 & Arista Hotel & 96 & 0 \\
\hline 2 & The Aryaduta Hotel & 112 & 0 \\
\hline 3 & Sanjaya Hotel & 82 & 0 \\
\hline 4 & Novotel Hotel & 126 & 0 \\
\hline 5 & The Daira Hotel & 117 & 35 \\
\hline 6 & Sintesa Peninsula Hotel & 91 & 0 \\
\hline 7 & PT. Grand Central Hotel (Hotel Aston) & 110 & 0 \\
\hline 8 & Horison Ultima Hotel & 116 & 35 \\
\hline 9 & Swarna Dwipa Hotel & 90 & 0 \\
\hline 10 & Princess Hotel & 73 & 0 \\
\hline 11 & Royal Asia Hotel & 69 & 20 \\
\hline 12 & Sahid Imara Hotel & 62 & 0 \\
\hline 13 & Grand Zuri Hotel & 113 & 12 \\
\hline 14 & Emilia Hotel & 83 & 0 \\
\hline 15 & Rio City Hotel & 72 & 22 \\
\hline 16 & Quin Centro Hotel & 78 & 23 \\
\hline 17 & Graha Sriwijaya Hotel & 60 & 15 \\
\hline 18 & Anugrah Hotel & 42 & 12 \\
\hline 19 & Budi Hotel & 49 & 0 \\
\hline 20 & Zury Express Hotel & 59 & 12 \\
\hline 21 & Alam Sutra Hotel & 39 & 0 \\
\hline 22 & Best Skip Hotel & 26 & 8 \\
\hline 23 & Wisata Hotel & 32 & 10 \\
\hline 24 & Garuda Mas Hotel & 46 & 10 \\
\hline 25 & Max One Hotel & 89 & 20 \\
\hline 26 & Duta Hotel & 82 & 20 \\
\hline 27 & Grand Duta Hotel & 79 & 0 \\
\hline 28 & De Premium Hotel & 23 & 0 \\
\hline 29 & Feodora Airport Hotel & 23 & 0 \\
\hline 30 & Sofyan Inn Malaka Hotel & 20 & 0 \\
\hline 31 & Azza Hotel & 30 & 15 \\
\hline 32 & Amaris Hotel & 49 & 23 \\
\hline 33 & Fave Hotel & 75 & 0 \\
\hline 34 & Swarna Dwipa Residence Hotel & 15 & 0 \\
\hline 35 & Red Planet Hotel & 89 & 0 \\
\hline 36 & Anida Hotel & 12 & 0 \\
\hline 37 & Classie Hotel & 29 & 15 \\
\hline 38 & Raden Hotel & 19 & 12 \\
\hline 39 & Rian Cottage & 20 & 0 \\
\hline 40 & Belvena Hotel & 15 & 10 \\
\hline 41 & Paradise Hotel & 16 & 0 \\
\hline 42 & Bukit Indah Hotel & 19 & 0 \\
\hline 43 & Sukarami Hotel & 22 & 14 \\
\hline 44 & Majestic Hotel & 14 & 10 \\
\hline \multicolumn{2}{|r|}{ TOTAL } & 2583 & 353 \\
\hline
\end{tabular}

Source: Culture and Tourism Department of Palembang, 2015

The instruments of this study were adopted from previous researches, thus writers simply ensured the content validity. Data collection was performed by the use of the following instruments: 
To collect the data on employees' English communication competence, a speaking test was designed and recorded to be analyzed by qualified raters. The speaking test was evaluated using CSRS (Conversational Skills Rating Scale) scoring rubric.

Working achievement is the achieved result in performing the assigned task responsibly based o experience and sincerity (Nasution 2002).

Tabel 2. Variable Working Achievement

\begin{tabular}{llll}
\hline $\begin{array}{l}\text { Working } \\
\text { Achievement } \\
\text { (Nasution, }\end{array}$ & 1. $\begin{array}{l}\text { Working } \\
\text { Quality }\end{array}$ & $\begin{array}{l}\text { Working } \\
\text { 2002:99) }\end{array}$ & $\begin{array}{l}\text { The evaluation criteria are working accuracy, } \\
\text { skill, precition, and neatness. The characteristic } \\
\text { of working result is based on the established } \\
\text { standard. }\end{array}$ \\
3. Initiative & $\begin{array}{l}\text { 2. } \begin{array}{l}\text { The evaluation criteria conform the superior } \\
\text { instruction, company regulation, and attendance. }\end{array} \\
\text { 3he evaluation criteria emphasize on the } \\
\text { liveliness and passion of completing work } \\
\text { without relying on superior instruction. }\end{array}$ \\
\hline
\end{tabular}

The writer evaluated the content validity by examining the plan and the procedures used in constructing the instrument. Content validity is the extent to which the questions on the instrument and the scores of these questions are representative of all the possible questions that a researcher could ask about the content or skills (Cresswell 2005). Since both the CSRS Scoring Rubric and Working Achievement Questionnaire are ready-made instruments which have been used in previous studies, the writers in this study were not required to conduct the validity and reliability test. Furthermore, no modification was made during the implementation of these instruments, so the items were originally used to find out the information related to both the independent and dependent variables.

This research used a Simple linear regression. In this study, this test aimed to find out corelation between independent variable $(\mathrm{X})$ namely English comunicaton competence and dependent variable (Y) namely working achievement.

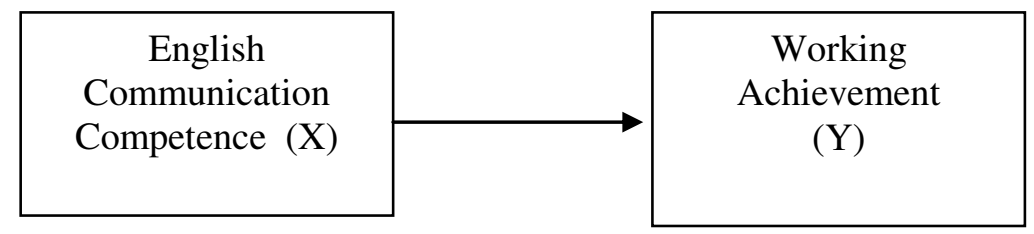

Figure 1. Research Model

\section{Result and Discussion}

To obtain rational and reliable research findings, the following steps are described :

Based on the study done to 353 star hotel employees in Palembang, the followings are the identification of them:

Table 3. Respondents Profile based on Gender

\begin{tabular}{ccc}
\hline Gender & Respondents & Percentage (\%) \\
\hline Male & 211 & 60 \\
Female & 142 & 40 \\
Total & 353 & 100
\end{tabular}

Table 3 indicates that there were 211 male employees (60\%) and 142 female (40\%) involved in this study. Male employees mostly handled the technical work in the hotel and had bigger opportunity to deal with the hotel guests. Unlike the male staffs, female staffs were usually placed as back office staffs which lessened their opportunity to interact directly with the hotel guests. 
Table 4. Respondents Profile based on Age

\begin{tabular}{ccc}
\hline Gender (years old) & Respondents & Percentage (\%) \\
\hline $20-27$ & 162 & 46 \\
$28-35$ & 134 & 38 \\
$>35$ & 57 & 16 \\
Total & 353 & 100 \\
\hline
\end{tabular}

Table 4 illustrates three different categories of respondents' age namely 20 - 27 years old (162 people with the percentage of 46\%), 28 - 35 years old (134 people with the percentage of $38 \%$ ), and more than 35 years old (57 people with the percentage of 16\%). Most respondents were still in productive period to work.

Table 5. Respondents Profile based on Educational Background

\begin{tabular}{ccc}
\hline Educational & Respondents & Percentage (\%) \\
Background & & \\
\hline Senior High School & 14 & 4 \\
Diploma III & 127 & 36 \\
Bachelor (S1) & 205 & 58 \\
Master (S2) & 7 & 2 \\
Total & 353 & 100 \\
\hline
\end{tabular}

The data shows that there were 14 respondents (4\%) graduated from Senior High School, 127 respondents (36\%) were from Diploma III, 205 respondents (58\%) had Bachelor degree, and 7 respondents $(2 \%)$ had a Master degree.

Table 6. Respondents Profile based on Working Period

\begin{tabular}{ccc}
\hline Working Period (years) & Respondents & Percentage $(\%)$ \\
\hline $0-1$ & 77 & 22 \\
$2-3$ & 240 & 68 \\
$4-5$ & 29 & 8 \\
$>5$ & 7 & 2 \\
Total & 353 & 100 \\
\hline
\end{tabular}

Table 6 shows that the working period of respondents varied from less than a year to more than five years. It was found that most respondents had been working for 2 to 3 years with the total of 240 employees (68\% of the total sample of this study).

Table 7. Respondents Profile based on Marital Status

\begin{tabular}{ccc}
\hline Marital Status & Respondents & Percentage (\%) \\
\hline Menikah & 127 & 36 \\
Belum Menikah & 226 & 64 \\
Total & 353 & 100 \\
\hline
\end{tabular}

Table 7 shows that the respondents of this study were mostly dominated by single employees with the percentage of $64 \%$. Single employees were assumed to provide bigger advantage for the company. They might focus on the working assignment since they id not set the time limit and certain responsibility toward the family.

Table 8 above shows that English Communication Competence variable obtained $t_{\text {value }}$ of 2.702 which was higher than the $t_{\text {table }}$ 2.011. This implies the independent variable influenced the dependent variable. Viewed from the significant value, it was obtained that the value (0.009) was lower than 0.05 which means English comunication competence positively and significantly influenced working achievement variable. The standard coefficient value of 
regression model showed that the constants value was 23.463 and English comunication competence's coefficient value was 0.367. Definitely, it could be implied that English comunication competence positively influenced working achievement.

Table 8. Partial Test Result

\begin{tabular}{|c|c|c|c|c|c|}
\hline $\begin{array}{l}\text { Independend } \\
\text { Variable }\end{array}$ & Coefficient & $\mathrm{T}$ & Sig. & $\begin{array}{l}\text { Hypothetical } \\
\text { Direction }\end{array}$ & Information \\
\hline $\begin{array}{l}\text { Constant } \\
\text { English }\end{array}$ & 23,463 & 4,006 & 0,000 & & \\
\hline $\begin{array}{l}\text { Communication } \\
\text { Competence }\end{array}$ & 0,367 & 2,702 & 0,009 & positive & H1 Accepted \\
\hline
\end{tabular}

The questionnaire result indicated that most of the respondents were dominated by male instead of female. Male employees mostly handled the technical work in the hotel and had bigger opportunity to deal with the hotel guests. Unlike the male staffs, female staffs were usually placed as back office staffs which lessen their opportunity to interact directly with the hotel guests. Viewed form the age, respondents were about $20-27$ years old. In this time, employees were still in the productive age. Several other information of respondent profile were also obtained in the beginning part of the questionnaire such as educational background, working period, and marital status.

The normality test implies that the data obtained was distributed normally since Kolmogorov-Smirnov test shows that the significance (2-tailed) was $0.089 . \mathrm{R}^{2}$ value described by model summary in table 8 was $0.132(13.2 \%)$ which means working achievement variable was explained by english comunication competence variable. While the rest $86.8 \%$ of working achievement variable could be explained by other undefined variable.

Table 7 shows that English comunication competence variable obtained was $t_{\text {value }}$ of 2.702 which was higher than the $t_{\text {table }}$ 2.011. This implies that the independent variable influenced the dependent variable. Viewed from the significant value, it was obtained that the value (0.009) was lower than 0.05 which means English comunication competence positively and significantly influenced working achievement variable. The standard coefficient value of regression model showed that the constants value was 23.463 and English comunication competence's coefficient value was 0.367. Definitely, it could be implied that English comunication competence positively influenced working achievement..

\section{Conclusion}

Based on the formulation of problems, data processing, result, and discussion of this study, it could be concluded that: Firstly, this study showed that there was significant influence of English ccommunication competence towards Palembang star hotel staffs' working achievement which was indicated by $\mathrm{r}^{2}$ value. $\mathrm{R}^{2}$ value described by model summary in table 8 was $0.132(13.2 \%)$ which means working achievement variable was explained by english comunication competence variable. While the rest $86.8 \%$ of working achievement variable could be explained by other undefined variable. Secondly, English Comunication Competence variable obtained was $t_{\text {value }}(2.702)$ while the $t_{\text {table }}$ value was 2.011 with the significance level of $0.009<0.05$. This means English Comunication Competence positively and significantly influenced Palembang star hotel employees' working achievement.

Several suggestions are addressed considering the findings of this study. First, it is hoped that hotel employers should consider the development of employees' English communication competence in order to improve the working achievement. Second, reflecting the necessity of hotel employees language competence development, training advancement program might be taken into account. Implementing additional regulations in hotel environment such as English 
speaking day program is optional to facilitate and support employees' language development toward encoutering international event in Palembang (Asian Games 2018). Third, it is expected that future researchers might develop this research issue by involving other variables which might contribute to the working achievement variable.

Several limitations were drawn as the following: This study required language competence data in the form of employees' speaking activity recording which was restricted in particular big hotels. The hotel management argued that data collection required by writers was time consuming regarding the employees shifting schedule. Second, since the data collection allocated longer time for recording, respondents did not accurately complete the questionnaire's items.

\section{References}

ASEAN Secretariat: Charter of the Association of Southeast Asian Nations (2008b) [internet]. Jakarta. Indonesia: Association of Southeast Asian Nations. [Cited in 2017 January 11]. Available form http://www.asean.org/archive/publications/ASEAN-Charter.pdf

Bagaric V. 2007. Defining communicative competence. Metodika. 8(1): 97-103.

Chomsky N. 1965. Aspects of the Theory of Syntax. Cambridge. Mass.: M.I.T. Press.

Cooper DR, Schindler PS. 2001. Business Research Methods. (7th ed.). New York: McGrawHill Companies Inc.

Davis FD, Bagozzi RP, Warshaw PR. 1996. Extrinsic and Intrinsic Motivation to Use Computers in the Workplace. Journal of Applied Social Psychology. 22(14): 1111-1132

Didiot-Cook H, Gauthier V, Scheirliackx K. 2000. Language needs in business, a survey of European multinational companies. CEMS Executive Office.

Dulyadaweesid N. 2013. Thailand's Educational Strategic Plan in Preparation for the ASEAN Community. Proceeding. Paper presented at the Asian Conference on Education 2013. Japan: Osaka University

EF EPI: EF English Proficinecy Index [internet]. 2015. Looking Ahead: EFSET the EF Standard English Test: Executive summary. [Cited in 2017 January 14]. Available from http://www.kernvakengels.nl/english-in-54-countries.pdf.

Hasibuan MSP. 2008. Manajemen Sumber Daya Manusia 11ed. Jakarta: PT Bumi Aksara. Hymes DH. 1972. On Communicative Competence. USA: Penguin Education, Penguin. Books Ltd.

Mangkunegara AP. 2009. Evaluasi kinerja Sumber daya manusia. Bandung: Refika Aditama.

Nasution H. 2002. Pengelola Manajemen Sumber Daya Manusia. Medan: Cetakan Permata. USU Press.

Nurlaila N. 2003. Hubungan antara kemampuan berbahasa Inggris dengan kinerja karyawan PT. Elang Express Surabaya [Thesis]. Surabaya, Indonesia: Program Pascasarjana Universitas Airlangga.

Radford A. 1988. Transformational Grammar. Cambridge: Cambridge University Press.

Regina E, Chinwe UV. 2014. Strategies for developing communicative competence in English as a second language (ESL) situation. World Journal of Management and Behavioral Studies. 2(3): 74-79.

Rivai V. 2005. Manajemen Sumber Daya Manusia Untuk Perusahaan. Jakarta: PT. Raja Grafindo Persada

Sekaran U. 2000. Research Methods for Business, A Skill-Building Approach $3^{\text {rd }}$ edition. USA: John Wiley \& Sons, Inc.

Spitzberg BH. 2003. Methods of interpersonal skill assessment. New Jersey: Lawrence Erlbaum Associates.

Supomo B, Indriantoro N. 2002. Metodologi Penelitian Bisnis untuk Akuntansi dan Manajemen. Yogyakarta:BPFE.

Sutrisno E. 2011. Manajemen Sumber Daya Manusia. Jakarta: Kencana. 